\title{
HEALTH TOURISM MARKET IN POLAND AND CROATIA - FINANCIAL EFFECTS AND POTENTIALS
}

\author{
Daniel Dragičević \\ Hana Paleka
}

https://doi.org/10.20867/tosee.05.5

\begin{abstract}
Purpose - In recent decades, health tourism has developed as a strong trend, parallel with another global megatrend - the growing popularity of health awareness. Health tourism market, in the European Union, is a new and robust niche, with an estimated 56.0 million domestic and 5.1 million international arrivals in 2014. The purpose of this paper is to describe the main characteristics and to analyse some of the challenges of developing health tourism in Poland and Croatia. Also, the financial effects of these health tourism markets are compared and evaluated. Methodology - The comparative analysis of secondary data, including the statistics of health tourism financial effects in Poland and Croatia, is done. The methodology of the paper also includes description and analysis of the current strengths, weaknesses, opportunities and threats through a SWOT analysis of Polish and Croatian health tourism.

Findings - Research results show that there is reasonable ground to state that health tourism in Poland and Croatia can be a strong take-off point for their tourism in general, as well as an export product of particular significance for these countries. However, there are still many obstacles in this journey.

Contribution - This paper aims to draw the attention to research gap and strengthens the call for more empirical and statistical research on the role, development as well as economic outcomes of health tourism in European Union, and especially Poland and Croatia.

Keywords health tourism, development, financial effects, Poland, Croatia, SWOT analysis
\end{abstract}

\section{INTRODUCTION}

Visiting different countries for health purposes has a long history and tradition, especially in Europe. Health tourism, with a focus on good health, general wellbeing and its pursuit, is not a new phenomenon (Cook 2008, 3). For example, it is well known that the Ancient Greeks often travelled to Epidauria (on the Saronic Gulf) to visit the sanctuary of the healing god (Asklepios) who revealed remedies to them in their dreams. A similar tradition was present with Ancient Romans who constructed famous Baths of Caracalla with the ability to accommodate several thousand visitors. They remained in use for three centuries (until the siege of Rome, $537 \mathrm{AD}$ ). In the period from the $15^{\text {th }}$ to $17^{\text {th }}$ century, meagre sanitary conditions throughout Europe stimulated interest by the wealthy citizens in spas, mineral springs and the seaside for health purposes. These wealthy individuals would also travel to renowned medical schools for medical assistance (Swarbrooke and Horner 2007, 16). This continued into the $18^{\text {th }}$ and $19^{\text {th }}$ centuries where spa towns, particularly in the south of France, became famous for health cures, the sun, and escaping the cold climatic conditions in the north of Europe (Holden 2006, 21). 
ToSEE - Tourism in Southern and Eastern Europe, Vol. 5, pp. 219-232, 2019

D. Dragičević, H. Paleka: HEALTH TOURISM MARKET IN POLAND AND CROATIA - FINANCIAL ...

Nowadays, healthcare has become a global market, with emerging, developing and developed nations competing for health tourists. As a result of this, health tourism plays a vital role in the development of sustainable tourism, placing value on environmental quality, reducing seasonality, adjusting supply to specific customer demands, and financial growth of individual institutions providing health tourism services (Hodžić and Paleka 2018, 2). Health-care tourism, once treated as a miscellaneous activity within a destination, is now a prominent activity in many European countries (Gilbert and Van De Weerdt 1991, 5).

The primary objective of this paper is to describe the most important characteristics and to analyse some of the challenges of developing health tourism in Poland and Croatia. Also, the financial effects of these health tourism markets are compared and evaluated.

The paper is structured as follows. After the introduction, section 1 provides a brief review of the most relevant research in the field of health tourism. The methodology is described in second, while research results and the discussion of findings in the third section. The final section of the paper draws concluding remarks and directions for future research.

\section{LITERATURE REVIEW}

In recent years, there is a growing academic interest in health tourism all over the world (Connell 2006; Crooks et al. 2010; Carrera and Lunt 2010). Nevertheless, available literature often describes the nature of health tourists decision making (Connell 2013; Yeoh et al. 2013), history (Smith and Puczkó 2009; Connell 2011) and health tourism destinations (Cheung, 2015; Cohen 2008; Smith and Puczkó 2009; White 2009). On the other hand, economic effects of health tourism (Connell 2011; Morgan 2015; Reisman 2015 ) and the role of the government and public sector, in general, are less often discussed (Hall 2011; Hanefeld et al. 2014). Many researchers discuss and emphasise the importance of health tourism subsectors (Bookman and Bookman 2007; Connell 2006; Darwazeh 2011, Pollard 2012).

However, no unequivocal research on the financial effects of health tourism was found, and the review of previous literature indicates that there are limited related studies. In other words, only a few researchers have focused on the financial effects and expenditure of health tourism (Johnson et al. 2015, Loh 2014; Loh 2015, Ridderstaat et al. 2018 Hodžić and Paleka 2018).

Furthermore, many of the researchers mentioned above agree that there is a lack of precise definition, uniformity in procedure and costs, global legislation and a concise benchmark activity like sustainable indicators for health tourism.

The forerunner to the United Nations World Tourism Organization Health tourism, known as the International Union of Tourist Organizations (IUTO), offered one of the first definitions of health tourism as "the provision of health facilities utilizing the natural resources of the country, in particular mineral water and climate" (IUTO 1973, $7)$. Goodrich and Goodrich $(1987,217)$ were one of the first researchers who tried to 
ToSEE - Tourism in Southern and Eastern Europe, Vol. 5, pp. 219-232, 2019

D. Dragičević, H. Paleka: HEALTH TOURISM MARKET IN POLAND AND CROATIA - FINANCIAL ...

define health tourism in terms of the narrower concept of health-care tourism as "the attempt on the part of a tourist facility (e.g. hotel) or destination (e.g. Baden, Switzerland) to attract tourists by deliberately promoting its health care services and facilities, in addition to its regular tourist amenities."

As the concept of health tourism evolved, World Tourism Organization included the following aspects into its definition: medical care, sickness and well-being, rehabilitation and recuperation (WTO 2019). Even though the concept of health tourism is widespread, there is still no consensus among scientists and experts regarding this notion.

On the topic of defining and conceptualising health tourism, Smith and Puczkó's definition is most widely accepted. According to these authors, health tourism "comprises those forms of tourism which are centrally focused on physical health, but which also improve mental and spiritual well-being and increase the capacity of individuals to satisfy their own needs and function better in their environment and society (Smith and Puczkó 2014, 206)." Following this concept, health tourism can be divided into three interconnected subsectors - medical, wellness and spa tourism. Medical tourism involves people travelling for the sole purpose of undergoing medical treatments, interventions or therapies. In other words, curing illnesses is the core of medical tourism subsector. On the other hand, wellness tourism emphasises prevention and personal wellbeing. Spa tourism, as a mean for healing, relaxing or beautifying the body, is located in a sort of middle ground between health and wellness tourism (Hodžić and Paleka 2018, $3)$.

\section{DATA AND METHODOLOGY}

In order to investigate the health tourism market in the European Union, this paper has chosen the following countries: Poland and Croatia. A comparative analysis of secondary data, including the statistics of health tourism, financial effects in Poland and Croatia was done. Financial effects of health tourism in the European Union, in general, have also been separately analysed, through the categories of international and domestic arrivals as well as revenues. Research conducted by the European Parliament's Committee on Transport and Tourism (TRAN) in 2014 was taken as the basis for the analysis. This research was also a take-off point for comparative analysis of average trip revenues in Poland and Croatia (for health tourism and tourism in general). In order to analyse the global wellness economy and leading markets article utilized the data collected by the Global Wellness Summit and Institute.

Furthermore, the methodology of the paper also includes description method and analysis of the current strengths, weaknesses, opportunities and threats through a SWOT analysis of Polish and Croatian health tourism. 
ToSEE - Tourism in Southern and Eastern Europe, Vol. 5, pp. 219-232, 2019

D. Dragičević, H. Paleka: HEALTH TOURISM MARKET IN POLAND AND CROATIA - FINANCIAL ...

\section{RESULTS}

Health tourism is one of the most propulsive types of selective tourism in Europe, with $15 \%$ of all travel being motivated by issues concerning health - amounting to 203 million trips taken by Europeans each year (American Chamber for Commerce in Croatia 2018, 3).

Given the economic potential, various countries in the European Union opened their doors to health tourism in the last few decades. In 2014, the total size of the health tourism market in EU-28 was estimated to be "56.0 million domestic arrivals and 5.1 million international arrivals (from all over the world), totalling 61.1 million healthtourism arrivals within the EU-28. The total health-tourism market (international plus domestic trips) comprises $4.3 \%$ of all EU-28 arrivals, 5.8\% of domestic arrivals and $1.1 \%$ of international arrivals" (Mainil et al. 2017, 26).

\section{Graph 1: Financial effect of the health tourism market in EU-28 in 2014}

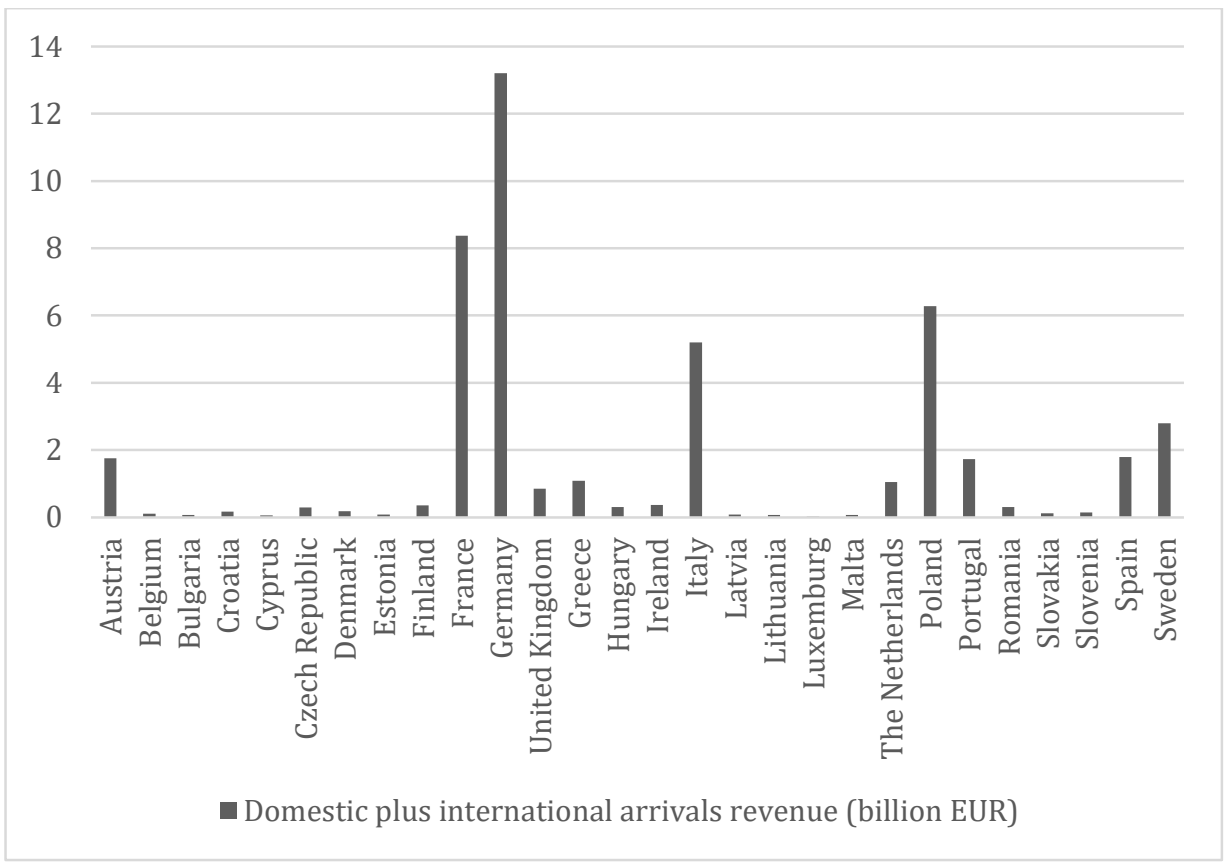

Source: Adapted by the authors according to Mainil et al. (2017)

The data above indicates that health tourism sector has a great potential in EU-28 since it realized 46.9 billion EUR of revenues in 2014, which is equal to $0.3 \%$ of the EU-28 gross domestic product. The sector plays a significant role for tourism in general - it made $4.6 \%$ of overall tourism revenues in EU-28 in 2014. It is also interesting to notice that more than three-quarters of these revenues are the contribution of five Member States: Germany, France, Poland, Italy and Sweden. 
ToSEE - Tourism in Southern and Eastern Europe, Vol. 5, pp. 219-232, 2019 D. Dragičević, H. Paleka: HEALTH TOURISM MARKET IN POLAND AND CROATIA - FINANCIAL ...

Table 1: Wellness sector expenditures worldwide in 2015 and 2017

\begin{tabular}{|l|c|c|}
\hline \multirow{2}{*}{} & \multicolumn{2}{|c|}{$\begin{array}{c}\text { Expenditures } \\
\text { (EUR billions) }\end{array}$} \\
\cline { 2 - 3 } & $\mathbf{2 0 1 5}$ & $\mathbf{2 0 1 7}$ \\
\hline North America & 194.4 & 213.9 \\
\hline Europe & 174.3 & 186.6 \\
\hline Asia - Pacific & 100.2 & 121.0 \\
\hline Latin America & 27.4 & 30.8 \\
\hline Middle East & 7.5 & 9.5 \\
\hline Africa & 3.8 & 4.2 \\
\hline TOTAL - WELLNESS & $\mathbf{5 0 7 . 6}$ & $\mathbf{5 6 5 . 9}$ \\
TOURISM INDUSTRY & & \\
\hline
\end{tabular}

Note: Monetary values were converted from USD to EUR (Eurostat, 2019)

Source: Global Wellness Institute (2019)

Table 1 shows the wellness sector, which comprises two-thirds of the health tourism market (Mainil et al. 2017, 9), as stable and growing globally. In Europe, the average annual growth rate for 2015 and 2017 period was $4.4 \%$. Compared to this, in the mentioned period, tourism has grown by $3.3 \%$ (UNWTO 2018, 5).

\subsection{Health tourism in Poland}

The total contribution, in 2017, of Travel \& Tourism to GDP in Poland was $4.5 \%$ of GDP and it is forecasted to rise by $5.5 \%$ of GDP in 2028. For the same year, it directly supported 332,000 jobs (2.0\% of total employment) and is expected to rise by $2.9 \%$ up to 448,000 jobs ( $2.7 \%$ of total employment) in 2028 (WTTC 2018).

The Eastern and Central European countries have begun to take a significant share of the health tourism market by using the advantages of European Union membership and low labour costs. These countries are turning into popular health tourism destinations, due to lower costs of health tourism products. In the European Union, Belgium, Hungary, Czech Republic and Poland are rapidly becoming popular health tourism destinations.

According to the Polish Association of Medical Tourism, 488,000 of foreign patients in 2014 came to Poland for medical treatment (PAMT 2019). This country is considered to be a good practice in planning and directing the European Union's Structural and Investment Funds to stimulate the development and growth of the health tourism market. In addition to this, health tourism was listed as one of fifteen priority areas of the Polish economy in the three - year economic strategy for the 2012 - 2015 period, with both national subsidies and European Union funds provided for its development. According to the Polish Tourism Organization data 1,163,000 EUR was allocated for the implementation of the three-year program for the promotion of health tourism and classical tourism in the period from 2016 to 2019 (American Chamber for Commerce in Croatia 2018, 10).

At present, Poland is one of the most popular health tourism destinations in Central Europe, with spa tourism as one of the most attractive subsectors. Poland can boast with more than 45 different licensed spa destinations that could attract both visitors searching 
ToSEE - Tourism in Southern and Eastern Europe, Vol. 5, pp. 219-232, 2019

D. Dragičević, H. Paleka: HEALTH TOURISM MARKET IN POLAND AND CROATIA - FINANCIAL ...

for specific treatment for their disease, as well as tourists looking for various tourist values.

Table 2: Financial effects of domestic and international health tourism in Poland in 2014

\begin{tabular}{|l|c|c|c|c|c|c|}
\hline & \multicolumn{2}{|c|}{ Domestic arrivals } & \multicolumn{2}{|c|}{ International arrivals } & \multicolumn{2}{c|}{$\begin{array}{l}\text { International } \\
\text { departures spending }\end{array}$} \\
\hline & billion $€$ & $\begin{array}{c}\text { per } \\
\text { capita } \\
(000 €)\end{array}$ & billion $€$ & $\begin{array}{c}\text { per } \\
\text { capita } \\
(000 €)\end{array}$ & billion $€$ & $\begin{array}{c}\text { per } \\
\text { capita } \\
(000 €)\end{array}$ \\
\hline Total - EU-28 & 42.9 & 84.5 & 3.9 & 7.6 & 13.9 & 27.3 \\
\hline Poland & 6.2 & 161.0 & 0.1 & 2.5 & 0.4 & 10.3 \\
\hline
\end{tabular}

Source: Adapted by the authors according to Mainil et al. (2017)

Regarding health tourism revenues in Poland, it is visible from the results above that the domestic arrivals section is rather high, taking $14.4 \%$ of total EU-28 domestic arrivals. The share itself points to the fact that Poland is one of the leaders and an example of good practice. Although the international arrivals share is much lower $(2.3 \%$ of EU-28 total), it is still significant for the Polish tourism sector in general. When analysing per capita numbers, the domestic arrivals section should be highlighted because it is significantly higher (almost 100\%) than the EU-28 average. Other per capita sections are much lower than the EU-28 average. Following table evaluates the present situation and market potential of health tourism in Poland.

\section{Table 3: SWOT Analysis of health tourism in Poland}

\begin{tabular}{|c|c|}
\hline Strengths & Weaknesses \\
\hline 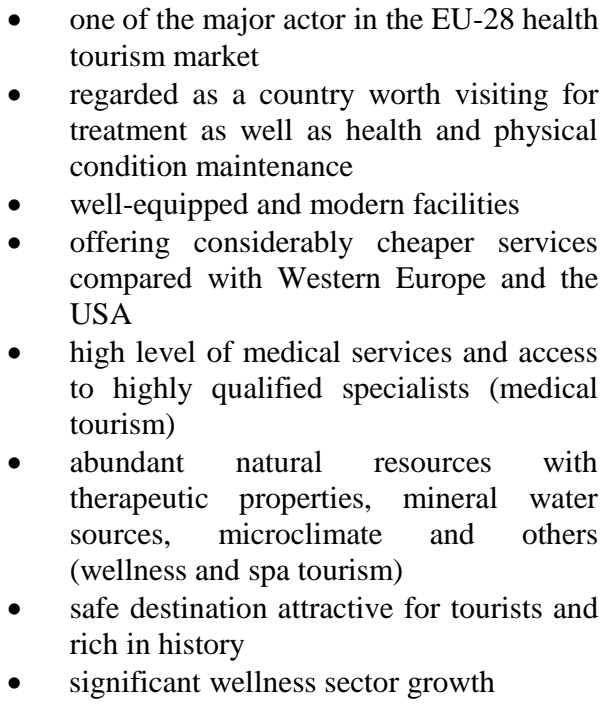 & $\begin{array}{l}\text { - a problem of defining health tourism as } \\
\text { a term } \\
\text { an unused potential of member states' } \\
\text { patients (medical tourism) } \\
\text { - } \text { weak cooperation within health tourism } \\
\text { establishments } \\
\text { - lack of planned and consistently } \\
\text { implemented promotion } \\
\text { need for public-private partnerships } \\
\text { (medical tourism) } \\
\text { a low number of agencies involved with } \\
\text { the promotion of health tourism }\end{array}$ \\
\hline
\end{tabular}


ToSEE - Tourism in Southern and Eastern Europe, Vol. 5, pp. 219-232, 2019

\begin{tabular}{|c|c|}
\hline Opportunities & Threats \\
\hline 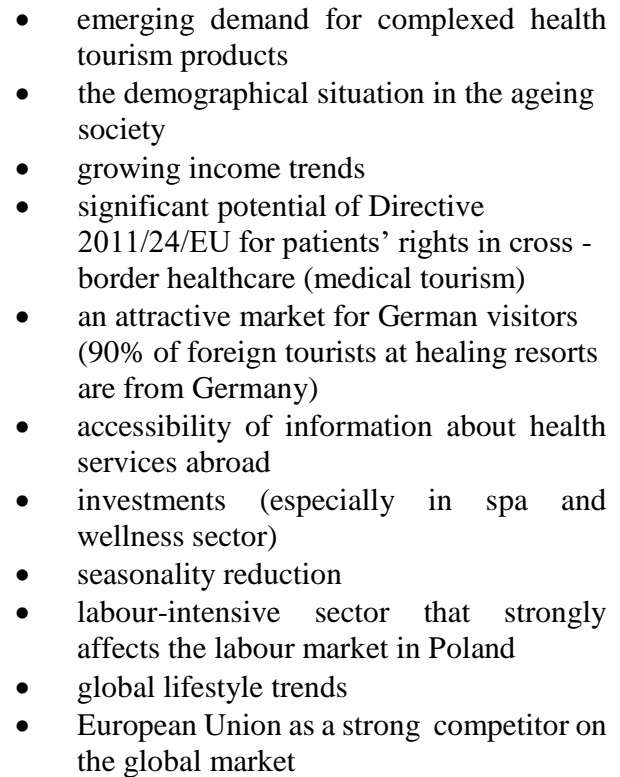 & $\begin{array}{ll}\text { - } & \text { strong global competition } \\
\text { - } & \text { strong local competition (Hungary) } \\
\text { - } & \text { lack of legislation and statistics } \\
\text { - } & \text { increased quantity - decreased quality } \\
\text { - } & \text { high level of skills required could mean } \\
\text { that the sector struggles to find enough } \\
\text { employees } \\
\text { loss and degradation of natural } \\
\text { resources } \\
\text { air pollution - Polish cities make up } 33 \\
\text { of the } 50 \text { most polluted cities in Europe }\end{array}$ \\
\hline
\end{tabular}

Source: Authors' research

In the European Union, Poland is regarded as a country worth visiting for treatment as well as health and physical recuperation. Besides, Poland is named as one of the fastest growing markets for wellness tourism trips (average annual growth rate is $11.7 \%$ in 2013-2015 and $14.7 \%$ in 2015-2017, according to Global Wellness Institute). Wellness and spa subsectors are main revenue generators at the moment, but medical tourism is not negligible at all. When talking about that subsector, one must highlight the globally recognised quality and standard of healthcare in Poland. The country is perceived as a place where health services are inexpensive, and facilities are modern and adequately equipped.

However, further development of entire health tourism sector requires primarily coordination for gathering reliable data, as well as building cooperation and networking among institutions interested in sending and hosting tourists. Access to the European Union has created favourable conditions and served as a sound basis for the new directions of the health tourism development in Poland.

Finally, the identified threats point to environmental degradation caused by pollution and urban sprawl, among other causes. Additionally, one of the most significant threats is the rising of global and local competitors. Whittaker $(2008,272)$ claims that "the expected economic benefits of health and/or medical tourism increasingly sharpened the rivalry between the developed and developing countries." 
ToSEE - Tourism in Southern and Eastern Europe, Vol. 5, pp. 219-232, 2019

D. Dragičević, H. Paleka: HEALTH TOURISM MARKET IN POLAND AND CROATIA - FINANCIAL ...

\subsection{Health tourism in Croatia}

Over the last few decades, tourism became a significant economic activity in Croatia. The country is recognized as one of the most attractive destinations in the Mediterranean.

The total contribution of Croatias`Travel \& Tourism to GDP, in 2017, was $25.0 \%$ of GDP and it is forecasted to rise by $31.7 \%$ of GDP in 2028. This is a significantly larger share of GDP when compared to previously introduced numbers for Poland. At the same time, in 2017 , Travel \& Tourism directly supported 138,000 jobs $(10.1 \%$ of total employment) and it is expected to rise by $1.4 \%$ to 158,000 jobs (11.8\% of total employment) in 2028 (WTTC 2018).

Health tourism as a type of tourism employs 10,000 people and annually generates only about EUR 300 million in revenues from health services, which makes for less than 3\% of total revenues from tourism in Croatia (American Chamber of Commerce in Croatia 2018,3). With its low - cost treatment and a high standard of care, Croatia is slowly but surely establishing a name for itself as a health tourist destination. Health tourism offer is based more on dentistry and cosmetic surgery, spas and health resorts, and less on hospital treatment.

Table 4: Financial effects of domestic and international health tourism in Croatia in 2014

\begin{tabular}{|l|c|c|c|c|c|c|}
\hline & \multicolumn{2}{|c|}{ Domestic arrivals } & \multicolumn{2}{|c|}{ International arrivals } & \multicolumn{2}{c|}{$\begin{array}{c}\text { International } \\
\text { departures spending }\end{array}$} \\
\hline & billion $€$ & $\begin{array}{c}\text { per } \\
\text { capita } \\
(000 €)\end{array}$ & billion $€$ & $\begin{array}{c}\text { per } \\
\text { capita } \\
(000 €)\end{array}$ & billion $€$ & $\begin{array}{c}\text { per } \\
\text { capita } \\
(000 €)\end{array}$ \\
\hline Total - EU-28 & 42.9 & 84.5 & 3.9 & 7.6 & 13.9 & 27.3 \\
\hline Croatia & 0.2 & 46.6 & 0.1 & 23.3 & 0.1 & 23.3 \\
\hline
\end{tabular}

Source: Adapted by the authors according to Mainil et al. (2017)

Regarding health tourism revenues in Croatia, it is obvious from the results above that the situation is different from Poland. Domestic arrivals are rather low, $0.2 \%$ of total EU28 domestic arrivals. This is surely something that needs to be improved in future. Although the international arrivals share is much higher (2\% of EU-28 total), it is still lower than Polish. However, per capita numbers show that the real potential lies in the international arrivals section which, for Croatia, is three times bigger than EU-28 average and almost ten times bigger than the Polish. However, both countries are still considered to be in the early stages of development, with bright future predicted - growth trends are positive since 2013 . 
ToSEE - Tourism in Southern and Eastern Europe, Vol. 5, pp. 219-232, 2019

D. Dragičević, H. Paleka: HEALTH TOURISM MARKET IN POLAND AND CROATIA - FINANCIAL ...

\section{Table 5: SWOT Analysis of health tourism in Croatia}

\begin{tabular}{|c|c|}
\hline Strengths & Weaknesses \\
\hline 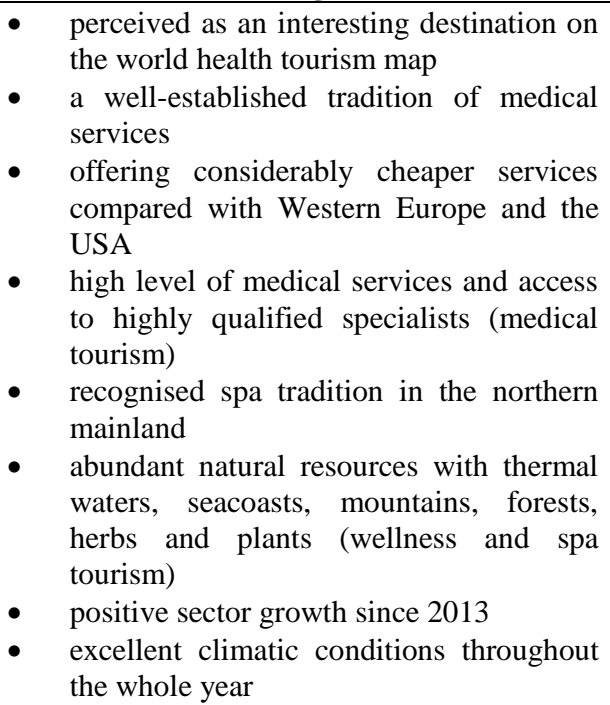 & 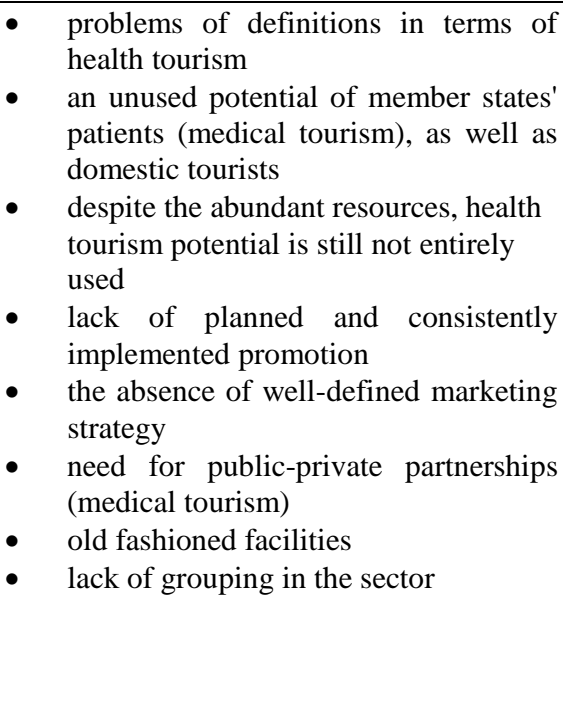 \\
\hline Opportunities & Threats \\
\hline 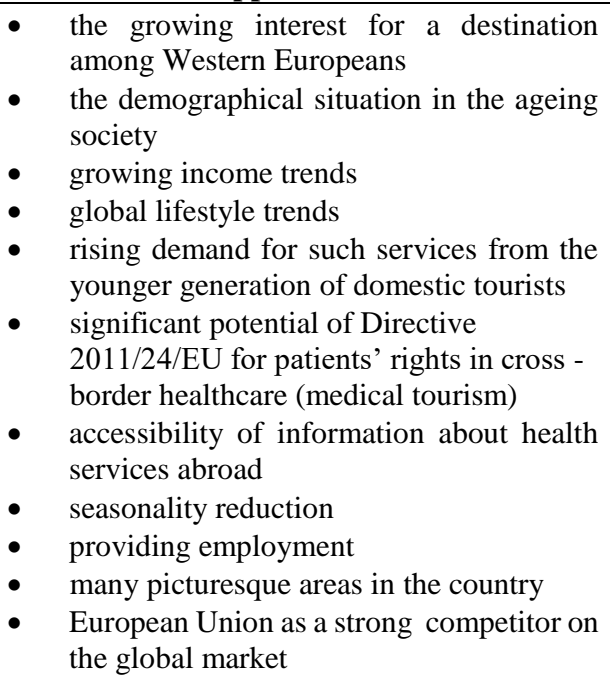 & $\begin{array}{ll}\text { - } & \text { strong global competition } \\
\text { - } & \text { strong local competition (Slovenia) } \\
\text { - } & \text { lack of legislation and statistics } \\
\text { - } & \text { increased quantity - decreased quality } \\
\text { - } & \text { high level of skills required could mean } \\
\text { that the sector struggles to find enough } \\
\text { employees } \\
\text { lack of financial resources and new } \\
\text { investment opportunities } \\
\text { - } \quad \text { political and economic instability } \\
\text { migration of professionals }\end{array}$ \\
\hline
\end{tabular}

Source: Authors' research

This SWOT analysis indicates that although there are significant challenges for developing health tourism in Croatia, there are also considerable potentials. The area is rich in natural resources, has excellent climate conditions throughout the whole year and recognised tradition of the medical and spa sector. 
ToSEE - Tourism in Southern and Eastern Europe, Vol. 5, pp. 219-232, 2019

D. Dragičević, H. Paleka: HEALTH TOURISM MARKET IN POLAND AND CROATIA - FINANCIAL ...

The continued evidence of political and economic instability in a wider region can affect the region's image adversely as a tourism destination. Rising problems with the adequate workforce are not insignificant either. However, according to many opportunities that this analysis emphasised, it is only a matter of time before Croatia manages to improve its offer, promote new products, and place itself firmly on the map of European or even global health tourism.

\subsection{Comparative analysis of health tourism potentials in Poland and Croatia}

After conducting the SWOT analysis for both countries, it is clear that considerable potential exists in the field of health tourism. The significance of health tourism is increasing in Poland and Croatia. It should be perceived as a potential driver for economic growth, seasonality reduction and sustainable development.

Tourism plays a significant role in both countries - generating gross domestic product, creating jobs and providing employment. Estimating the total size of the health tourism sector, in general, is difficult because of the limited and fragmented data. Besides, the overlapping definitions by different sources is a big obstacle as well. These issues should be in focus for further scientific research. However, some of the available data shows the apparent advantages of this specific tourism niche. Health tourism may not be the leading type of tourism when measured by the number of tourists, but it is still considered as one of the most finance-consuming market segments due to the high cost of services included. In 2014, the differences in EU-28 data for international health tourism revenues (€791 per trip) and international tourism revenues (€783 per trip) were small. The revenue rates for both categories for Poland and Croatia are below the EU-28 average. Croatia has significantly higher overall revenues from international tourism (€727 per trip) than Poland ( $€ 573$ per trip) while revenues from health tourism are higher in Poland - (€655 per trip) than in Croatia (€618 per trip) (Mainil et al. 2017, 34).

As countries with a recognised tradition, high-quality workforce and excellence in providing numerous health tourism services, Croatia and Poland have a strong foundation for the development of health tourism and all its subsectors. Although the potential is undeniable, there is still less specific and meaningful support in terms of strategic and financial backing on the part of the Croatian government, then Polish. The same is with a comprehensive and inclusive approach to the development of health tourism - there is a strong need for more cooperation and joint activity in these fields.

Some of the factors that could improve further development of health tourism in Poland and Croatia would be:

- $\quad$ extension and differentiation of the health tourism products as well as additional offer in that field

- $\quad$ the continuous use of the European Union funds

- $\quad$ the use of the Directive 2011/24/EU potential

- development of the scientific activity that would support the sustainable development of health tourism sector

- $\quad$ implementation of the new marketing techniques

- $\quad$ the use of opportunities linked to ageing trends as well as global lifestyle trends 
ToSEE - Tourism in Southern and Eastern Europe, Vol. 5, pp. 219-232, 2019

D. Dragičević, H. Paleka: HEALTH TOURISM MARKET IN POLAND AND CROATIA - FINANCIAL ...

According to Global Wellness Institute reports (2019), Poland has already been included as one of the top markets in health tourism. Graph 3 shows leading growth markets for wellness tourism trips, in the period from 2013 to 2015. Unfortunately, the indicators for health tourism, in general, are not available, just for the wellness subsector.

\section{Graph 2: Leading growth markets measured by wellness tourism trips from 2013 to 2015}

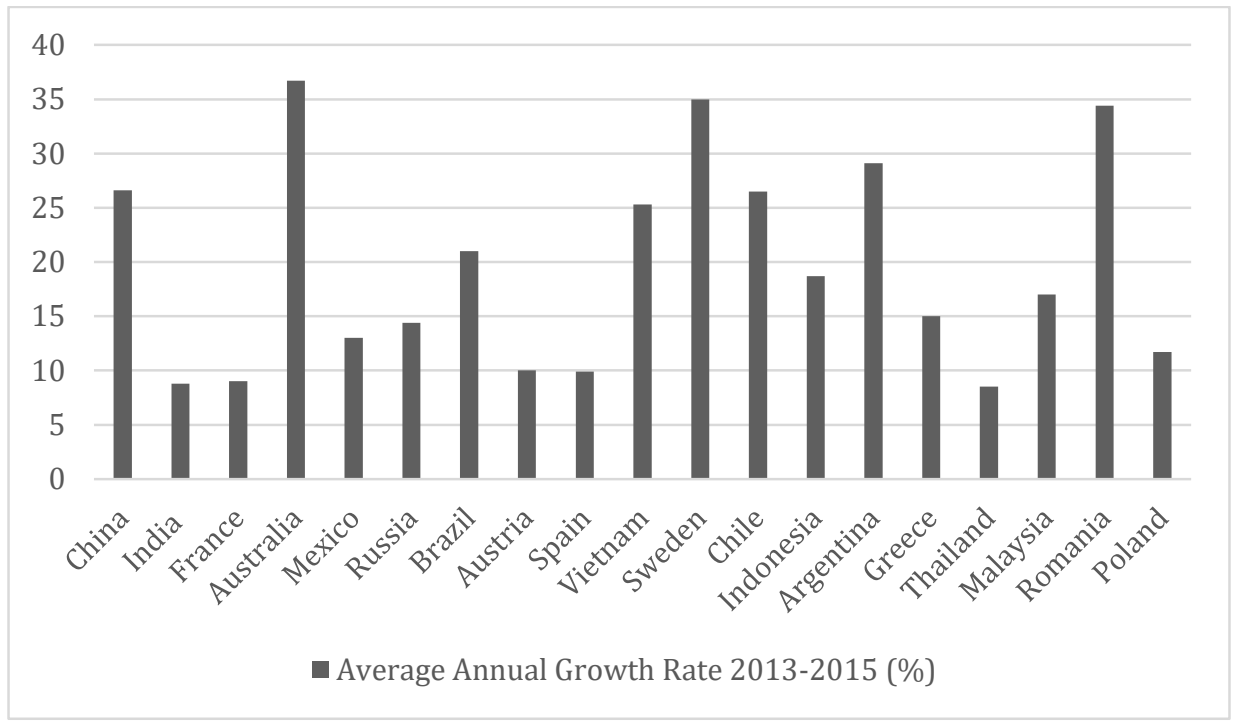

Source: Global Wellness Institute (2019)

The developing markets in Asia, Latin America, Middle East, and Europe have significant growth in wellness tourism trips in recent years. From the data presented, it is evident that the competition is rapidly growing and becoming economically significant on the global level. In Europe, Romania (34.4\%), Greece (15\%) and Poland (11.7\%) are the leaders of growth trends in wellness subsector.

\section{CONCLUSION}

Entire economic and financial systems are being affected by new trends such as healthy lifestyle and personal development, illness prevention and slowing down ageing. In the European Union, the health tourism sector has great potential. It contributed 46.9 billion EUR of revenues in EU-28 in 2014. Besides that, increasing the share of health tourism may lessen the seasonality of tourism, increase labour quality as well as sustainability. Access to the European Union has created favourable conditions for the new directions of the health tourism development in Poland and Croatia. Both countries show substantial potentials in this sector, by offering considerably cheaper but high-quality services. However, Poland is one-step ahead, according to the present situation and data analysed. In 2014, Polish health tourism revenues amounted to $13.4 \%$ of the EU-28 total, while Croatian to $0.4 \%$ of EU-28 total. Except for the fact that Poland is one of the key 
ToSEE - Tourism in Southern and Eastern Europe, Vol. 5, pp. 219-232, 2019

D. Dragičević, H. Paleka: HEALTH TOURISM MARKET IN POLAND AND CROATIA - FINANCIAL ...

players in the wellness and spa sector in Europe and globally, this country displays significant results in the medical subsector. Croatia's growing trends are positive since 2013, but there are still a lot of strategic and development prerequisites that need to be done.

Croatia still did not utilise the vast potential for health tourism development based on its natural healing remedies, like a marine aerosol in Adriatic coast and beneficial influence of its mild climate. Despite many barriers and limitations, health tourism potential is widely recognised and perceived as a vital niche in attracting new tourists and achieving significant financial results.

Analysis of secondary data points to the lack of quantitative research on health tourism in EU-28 (number of tourists, expenses etc.). In order to achieve strategic planning and brand building of health tourism as an export product, studies of this type are essential. It is also necessary to solve the problems of definitions in terms of health tourism. Without standardisation of terminology, collecting the member states data is not viable.

\section{REFERENCES}

American Chamber for Commerce in Croatia (2018), Recommendations for the Development of Medical Tourism in Croatia, Zagreb.

Bookman, M.Z. and Bookman, K.R. (2007), Medical Tourism in Developing Countries, Palgrave MacMillan, New York.

Carrera, P. and Lunt, N. (2010), "A European Perspective on Medical Tourism: The Need for a Knowledge Base", International Journal of Health Services, Vol. 40(3), pp. 469-484 https://doi.org/10.2190/HS.40.3.e .

Cheung, E. (2015), “A review of small-scale niche treatment providers”, Lunt, N., Horsfall, D. and Hanefeld, J., Handbook on medical tourism and patient mobility, Edward Elgar Publishing, Cheltenham, pp. 133-140.

Cohen, E. (2008), "Medical tourism in Thailand", Cohen, E., Explorations in Thai tourism, Emerald, Bingley, pp. 225-255.

Connell, J. (2006), “Medical Tourism: Sea, sun, sand and...surgery”, Tourism Management, Vol. 27(6), pp 1093-1100.

Connell, J. (2011), Medical tourism, CABI, Wallingford.

Connell, J. (2013), "Contemporary medical tourism: Conceptualisation, culture and commodification", Tourism Management, Vol. 34, pp. 1-13 https://doi:10.1016/j.tourman.2012.05.009.

Cook, Peta S. (2008), "What is health and medical tourism?", The annual conference of the Australian Sociological Association, 2 to 5 December 2008, The University of Melbourne, Victoria.

Crooks et al. (2010), "What is known about the patient's experience of medical tourism? A scoping review", BMC Health Services Research, Vol. 10(1), pp.1-12 https://doi.org/10.1186/1472-6963-10-266.

Darwazeh, D. (2011), Medical Tourism: Establishing a Sustainable Medical Facility.

Gilbert, D.C. and Van De Weerdt, Marlies (1991), "The health care tourism product in Western Europe", The Tourist Review, Vol. 46(2), pp. 5-10 https://doi.org/10.1108/eb058063.

Global Wellness Summit and Institute, n.d.: Global Wellness Economy Monitor, viewed 1 February 2019 , https://globalwellnessinstitute.org.

Goodrich, J.N. and Goodrich, G.E. (1987), "Health - care study - an exploratory study", Tourism Management, Vol. 8(3), pp. 217-222.

Hall, M.C. (2011), "Health and medical tourism: a kill or cure for global public health?", Tourism Review, Vol $66(1 / 2)$ pp. $4-15$

Hanefeld, J., Smith, R., Horsfall, D., and Lunt, N. (2014), "What Do We Know About Medical Tourism? A Review of the Literature With Discussion of Its Implications for the UK National Health Service as an Example of a Public Health Care System", Journal of Travel Medicine, Vol. 21(6), pp. 410-417 doi:10.1111/jtm.12147. 
ToSEE - Tourism in Southern and Eastern Europe, Vol. 5, pp. 219-232, 2019

D. Dragičević, H. Paleka: HEALTH TOURISM MARKET IN POLAND AND CROATIA - FINANCIAL ...

Hodžić, S. and Paleka, H. (2018), "Health Tourism in the European Union: Financial Effects and Future Prospects", 9th International Conference of the School of Economics and Business Conference Proceedings, pp. 162-174.

Holden, A. (2006), Tourism Studies and the Social Sciences, Routledge, London.

International Union of Tourism Organization (IUTO) (1973), Health Tourism, United Nations, Geneva

Johnson, T., Youngquist, J., Garman, A., Hohmann, S. and Cieslak, P. (2015), "Factors influencing medical travel into the United States", International Journal of Pharmaceutical and Healthcare Marketing, Vol. 9(2), pp. 118-135.

Loh, C. (2014), "Health tourism on the rise? Evidence from the balance of payments statistics", The European Journal of Health Economics, Vol. 15, pp. 759-766.

Loh, C. (2015), "Trends and structural shifts in health tourism: Evidence from seasonal time-series data on health-related travel spending by Canada during 1970-2010”, Social Science \& Medicine, Vol. 132, pp. 173-180.

Mainil, T., Eijgelaar, E., Klijs, J., Nawijn, J. and Peeters, P. (2017), Research for TRAN Committee - Health tourism in the EU: a general investigation, European Parliament, Policy Department for Structural and Cohesion Policies, Brussels.

Morgan, D. (2015), “Accounting for trade in healthcare”, Lunt, N., Horsfall, D. and Hanefeld, J., Handbook on medical tourism and patient mobility, Edward Elgar Publishing, Cheltenham, pp. 92-103.

Polish Association of Medical Tourism (PAMT), n.d.: Treatment in Poland, viewed 28 January 2019, http://www.pamt.org/.

Reisman, D. (2015), "The economics of health and medical tourism”, Lunt, N., Horsfall, D. and Hanefeld, J., Handbook on medical tourism and patient mobility, Edward Elgar Publishing, Cheltenham pp. 8291

Ridderstaat, J., Singh, D. and DeMicco, F. (2018), "The impact of major tourist markets on health tourism spending in the United States", Journal of Destination Marketing and Management, (Article in Press) https://doi.org//10.1016/j.jdmm.2018.05.003.

Smith, M. and Puczkó, L. (2009), "Historical overview", Smith M. and Puczkó, L., Health and wellness tourism, Routledge, New York, pp.21-38.

Smith, M. and Puczkó, L. (2014), Health, Tourism and Hospitality: Spas, Wellness and Medical Travel, Routledge, London.

Swarbrooke, J. and Horner, S. (2007.), Consumer Behaviour In Tourism, Butterworth-Heinemann, London.

Treatment Abroad, Pollard, K., Medical tourism: Key facts, viewed 28 January 2019. https://intuitionconnect.com/asset_files/Medical\%20Tourism\%20Fact\%20Sheet_0.pdf .

White, C. (2009), "Harnessing spa and wellness opportunities: An Australian experience", Bushell, R. and Sheldon, P.J., Wellness and tourism: Mind, body, spirit, place. Cognizant Communication Corporation, New York, pp.151-161.

Whittaker, A. (2008), "Pleasure and pain: Medical travel in Asia", Global Public Health, Vol. 3(3), pp. 271 290 doi:10.1080/17441690701463936

World Tourism Organization n.d., Exploring Health Tourism, viewed 1 February 2019, https://www.eunwto.org/doi/book/10.18111/9789284420209.

World Tourism Organization n.d., UNWTO Tourism Highlights, 2018 Edition, viewed 1 February 2019, https://www.e-unwto.org/doi/pdf/10.18111/9789284419876.

World Travel \& Tourism Council n.d., Travel \& Tourism Economic Impact 2018 (Croatia), viewed 15 February 2019, https://www.wttc.org/-/media/files/reports/economic-impact-research/countries 2018/croatia2018.

World Travel \& Tourism Council n.d., Travel \& Tourism Economic Impact 2018 (Poland), viewed 15 February 2019, https://www.wttc.org/-/media/files/reports/economic-impact-research/countries 2018/poland

Yeoh, E., Othman, K., and Ahmad, H. (2013), "Understanding medical tourists: Word-of-mouth and viral marketing as potent marketing tools", Tourism Management, Vol. 34, pp. 196-201 https://doi:10.1016/j.tourman.2012.04.010. 
ToSEE - Tourism in Southern and Eastern Europe, Vol. 5, pp. 219-232, 2019

D. Dragičević, H. Paleka: HEALTH TOURISM MARKET IN POLAND AND CROATIA - FINANCIAL ...

Daniel Dragičević, $\mathrm{PhD}$, Assistant Professor

University of Rijeka

Faculty of Tourism and Hospitality Management

Department of Micro and Macroeconomics

Primorska 42, 51410 Opatija, Croatia

Phone: +385-51-294683

E-mail: danield@fthm.hr

Hana Paleka, MA, Assistant

University of Rijeka

Faculty of Tourism and Hospitality Management

Department of Public Finance

Primorska 42, 51410 Opatija, Croatia

Phone: +385-51-689312

E-mail: hanap@fthm.hr 